Article

\title{
Drinking Water Source Protection for Surface Water Abstractions: An Overview of the Group Water Scheme Sector in the Republic of Ireland
}

\author{
Alec Rolston 1,*(D) and Suzanne Linnane ${ }^{2}$ \\ 1 An Fóram Uisce-The Water Forum, Dundalk, County Louth A91 K584, Ireland \\ 2 Centre for Freshwater and Environmental Science, Dundalk Institute of Technology, Dundalk, \\ County Louth A91 K584, Ireland; suzanne.linnane@dkit.ie \\ * Correspondence: alec@nationalwaterforum.ie
}

Received: 31 July 2020; Accepted: 28 August 2020; Published: 30 August 2020

check for updates

\begin{abstract}
Source protection is part of a multi-solution approach for the provision of safe drinking water. In the Republic of Ireland, community-led Group Water Schemes (GWS) provide treated drinking water to approximately 69,000 rural households. Between 2009 and 2019, preliminary source protection assessments were undertaken for 70 GWS abstracting from surface water sources to provide physical catchment characterisation and untreated and treated water quality analysis. Catchment areas upstream of abstraction points varied in size, with $51.5 \%$ being less than $5 \mathrm{~km}^{2}$ and only $10.7 \%$ being larger than $100 \mathrm{~km}^{2}$. The majority (91\%) of assessed GWS serve a population of less than 3000 people, and $94 \%$ supply less than $1500 \mathrm{~m}^{3}$ per day. Exceedances of the EU Drinking Water Regulations were recorded for 27 parameters, with the greatest number of exceedances due to total trihalomethanes followed by microbial contamination. The most frequent recommendation for improving GWS drinking water quality was associated with managing livestock access to local water bodies. Improving stakeholder engagement represented $38 \%$ of all recommendations made. Drinking water source protection measures and catchment-scale actions can be an additional model to assist in the delivery of Integrated Catchment Management and river basin management planning in the Republic of Ireland. For the GWS sector, challenges lie in securing resources to improve both source water and drinking water quality to deliver integrated catchment management plans for source protection.
\end{abstract}

Keywords: drinking water; source protection; catchment management; water quality

\section{Introduction}

Access to clean drinking water is a basic requirement for human life, and the protection of drinking water quality is a key concern to drinking water providers. However, the consistent supply of wholesome drinking water is a complex system requiring appropriate treatment processes. The scale, cost, and effectiveness of such systems is determined in the first instance by the quality and stability of the raw (untreated) water source from which the supply is abstracted [1]. Effective catchment management can help decrease the contamination of drinking water sources, potentially reducing treatment costs and reducing the production of treatment by-products and helping to minimise operational costs [2]. Source water protection is recognised as part of a multi-solution approach for the provision of safe drinking water with intervention at the source providing an early opportunity to contain potential risks, many of which are linked directly to land-use [1,3].

Water resources have been identified as being vulnerable to future climate change scenarios for the Republic of Ireland $[4,5]$ as drought magnitude and duration may increase in the future. The Republic 
of Ireland has been identified as one of six European countries where the impact of a $+2{ }^{\circ} \mathrm{C}$ global warming will be most extreme [6]. Weather extremes and climate variability directly impact the hydrological cycle, potentially resulting in consequences for both social and economic factors [7]. Consequently, increasing the resilience to climate change of both drinking water sources and the communities that rely on these sources can potentially have multiple ecosystem service benefits beyond solely improving the quality of drinking water supply. Source protection has the potential to deliver such ecosystem service benefits if delivered through integrated catchment management with significant buy-in from local communities [8].

Approximately $80 \%$ of all of the Republic of Ireland's drinking water is abstracted from surface waters [9]; however, despite significant resource investment in the implementation of the Water Framework Directive (2000/60/EC), almost half of all of the Republic of Ireland's surface waters are in unsatisfactory condition, achieving less than 'good' status $[9,10]$. Elevated nutrient concentrations (phosphorus and nitrogen) continue to be the most widespread water-quality problem in the Republic of Ireland. Eutrophication is recognised as the most significant threat to the quality of these surface waters, with one-third of rivers and lakes failing to meet their nutrient-based environmental quality standards [10]. Cyanobacterial blooms resulting from high nutrient loadings have potential human and animal health implications as a result of the production of microcystin toxins, with Mycrocystis spp. often the dominant species in cyanobacterial blooms in the Republic of Ireland, particularly within agricultural catchments [11,12]. Agriculture is identified as the most significant pressure, with $65 \%$ of the Republic of Ireland's land mass currently under agricultural production [13]. The importance of appropriate drinking water source protection measures should not be underestimated, and in the Republic of Ireland, the protection of drinking water sources is now prioritised on a national basis $[9,14,15]$.

In the Republic of Ireland, consumers receive their drinking water through one of five supply types-public water supplies; private wells in areas beyond any piped supply; Group Water Schemes (GWS) sourced from public supplies; privately sourced Group Water Schemes; and small private supplies [16,17]. Group Water Schemes are independent, community-owned enterprises consisting of two or more houses and are a means of providing piped, treated drinking water to rural areas where no other such supply exists [18]. The Republic of Ireland has a large rural population, with 1.74 million people (38\% of the population) living in rural areas [17]. The high rural proportion of the population living in rural areas in comparison to other European countries (EU average rural population of approximately $28 \%$ [19]) means almost $20 \%$ of households have drinking water supplies other than those obtained from public water supplies [9]. Approximately 69,000 rural households receive their drinking water from GWS [20], and GWS are located throughout the Republic of Ireland (Figure 1). All water supplies, including GWS, must deliver drinking water to their consumers that complies with the drinking water parameters as set out in the European Union Drinking Water Directive (98/83/EC) and associated regulations.

To reduce the risk of deteriorating raw water quality, the GWS sector adopted a multi-solution process and as such have long advocated the 'source-to-tap' approach to drinking water services provision [1]. The GWS sector has also recognised that the protection of drinking water sources is not only of benefit to human health but also ensures a cost-effective and sustainable approach to ensuring a high-quality product [1,9]. In 2012, the National Federation of Group Water Schemes (NFGWS), the oversight body for the GWS sector, developed a comprehensive strategy for source-protection planning for the privately sourced Group Water Schemes [21] to assist each GWS in developing and managing their own scheme-specific source protection plans. Although the first preliminary source protection assessments were initiated in 2009, the majority of assessments were initiated from 2014 onwards once funding was made available to individual GWS through the Rural Water Programme of the Irish Government.

While the GWS sector has been progressing source protection over the past 15 years, there has been mixed progress on source protection in the other four drinking water supply types. The 1989 
Surface Water Regulations [22] provide one of the first provisions for the formal development of drinking water source protection measures. Through this legislation, surface waters are classified in accordance with specific water quality standards that correspond to standard methods of treatment for drinking water provision. For surface water classified in the lowest water quality category and thus requiring multiple treatment processes for the provision of drinking water, the legislation states that "a sanitary authority shall prepare an action programme, including a timetable, for the improvement of the water quality". How many such plans were developed and implemented is unclear.

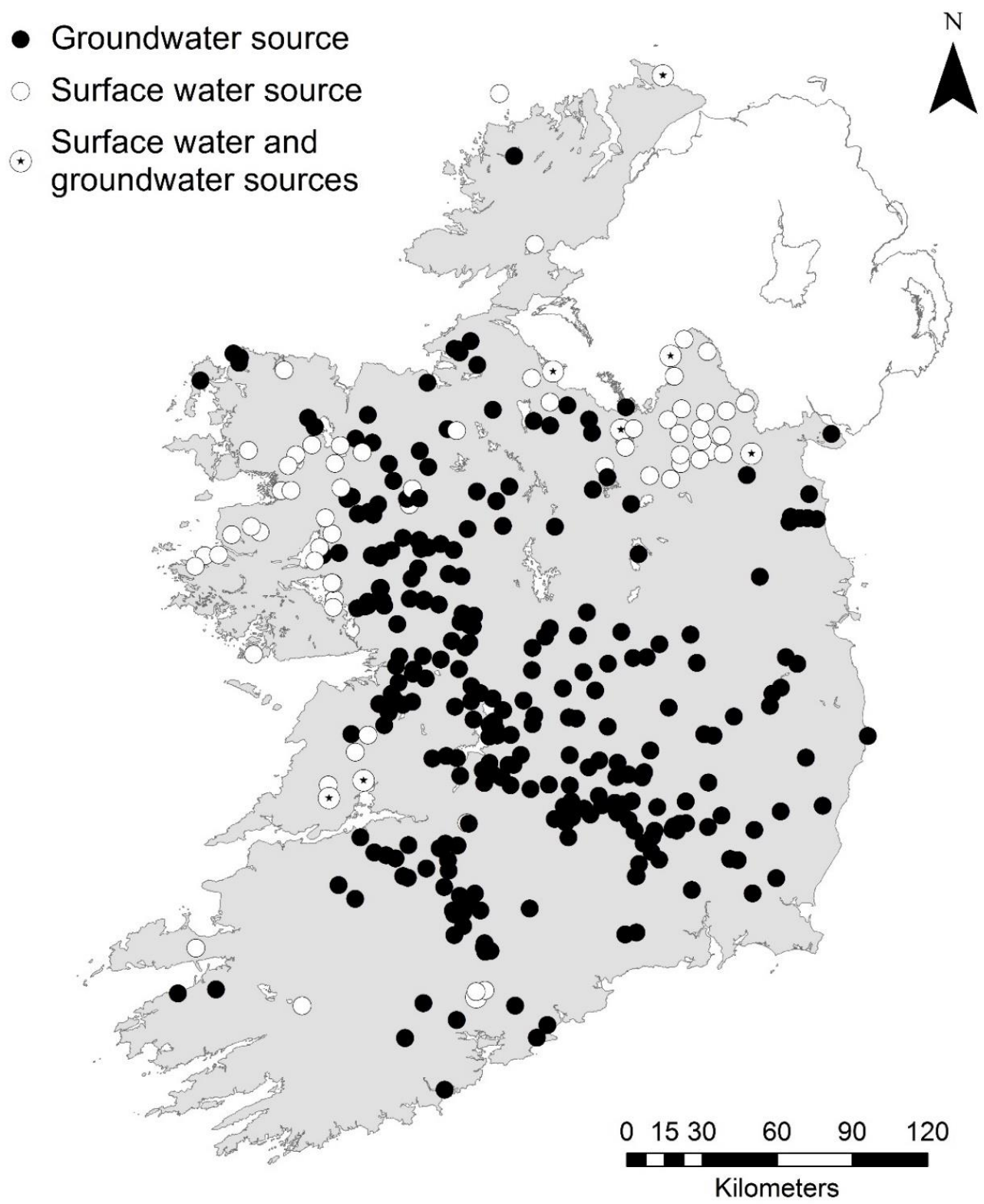

Figure 1. Location of and raw water source type for privately sourced Group Water Schemes that supply $4.4 \%$ of the total population of the Republic of Ireland.

Drinking water source protection processes were further prioritised in the Republic of Ireland's first WFD River Basin Management Plans (2009-2014), where consideration was given to the establishment of source protection zones to protect drinking water supplies in line with the WFD requirement for the identification of Drinking Water Protected Areas [23]. In 2014, the State water utility, Irish Water, was established to manage public water supplies and wastewater, replacing the previous drinking water management roles held by Local Authorities. Through their establishment, Irish Water was charged 
with the development of Drinking Water Safety Plans to identify all potential risks to individual water supplies, from catchment to consumer, and mitigation measures and procedures to be implemented to manage these risks [24]. To date, Irish Water's focus on reducing drinking water contamination risk has been through treatment or other measures rather than through source protection [9], with pilot source protection projects only initiated in 2019.

The country's second River Basin Management Plan (2018-2021) introduced a new collaborative approach to drinking water source protection among Irish Water, state agencies, and government departments with the aim of effectively managing and protecting drinking water sources 'at risk' from activities within the catchment area [9].

Given the multiple pressures acting on water bodies in the Republic of Ireland [10], drinking water source protection is likely to be a key component of the Republic of Ireland's 3rd River Basin Management Plan, the draft of which is due to be published in December 2020.

As the GWS sector is collaborative by nature with a strong community-based approach to water management and supply, they embody the concept of stakeholder engagement and comprise a combination of both bottom-up and top-down approaches to water management [15]. This philosophy of inclusiveness and partnership has allowed the sector to embrace the concept of 'integrated catchment management' as the basis for the effective implementation of source protection strategies. Communities can receive multiple benefits from becoming more involved in water management issues and by engaging with catchment management initiatives, such as improved drinking water quality; local communities can contribute to their implementation and ensure they remain cost-effective [8]. Focusing the level of stakeholder/community engagement at a local level where relevance and visibility of the impact of involvement can be identified (e.g., source protection measures) can enhance implementation and ultimately sustainability [25].

Article 14 of the EU Water Framework Directive (WFD) requires all member states to properly engage with all relevant stakeholders in a catchment (2000/60/EC, WFD). To do this, it is essential to appreciate and understand how local communities live in their catchments and use their water resources. Therefore, it is critical that local communities are involved in management and decision making related to protecting and, where necessary, improving their water resources.

This paper provides an overview of the role of the Group Water Scheme sector in delivering drinking water source protection in the Republic of Ireland and outlines the community-led actions for improving drinking water quality following the provision of preliminary drinking water source protection assessments.

\section{Materials and Methods}

Preliminary source protection assessments for 70 Group Water Schemes in the Republic of Ireland were initiated in 2009 using a standard process for each assessment [1] (Figure 2).

Following the identification of the water sources from which raw water is abstracted, an on-ground walkover assessment of the catchment upstream of the abstraction point was undertaken in partnership with Group Water Scheme representatives to discuss raw water and treated water issues and to identify potential pressures acting on raw water quality within the catchment. A desktop, GIS-based (ArcGIS version 10.2.1, ESRI 2013, Dublin, Republic of Ireland) catchment characterisation process was undertaken. Firstly, the surface water catchment area was delineated using a $20 \mathrm{~m}$ digital elevation model (DEM). Subsequently, a number of freely available GIS layers were used to characterise the physical components of the delineated catchment and how these may affect the quality of the raw water abstracted-i.e., the vulnerability of the raw water to contamination within the delineated catchment. GIS layers used for catchment characterisation included:

- Location of streams, lakes, and rivers, Co-Ordinated INformation on the Environment (CORINE) land cover, WFD ecological status of water bodies, and biotic indices [26];

- Bedrock geology, aquafer bedrock, aquifer vulnerability, and soil and subsoil types [27]; 
- WFD catchment and sub-catchment characterisation of water bodies, WFD risk assessment, and water quality status [28].

In addition, Ordnance basemaps and orthography were used to identify likely locations of domestic waste water treatment systems, such as septic tanks, within the source catchment.
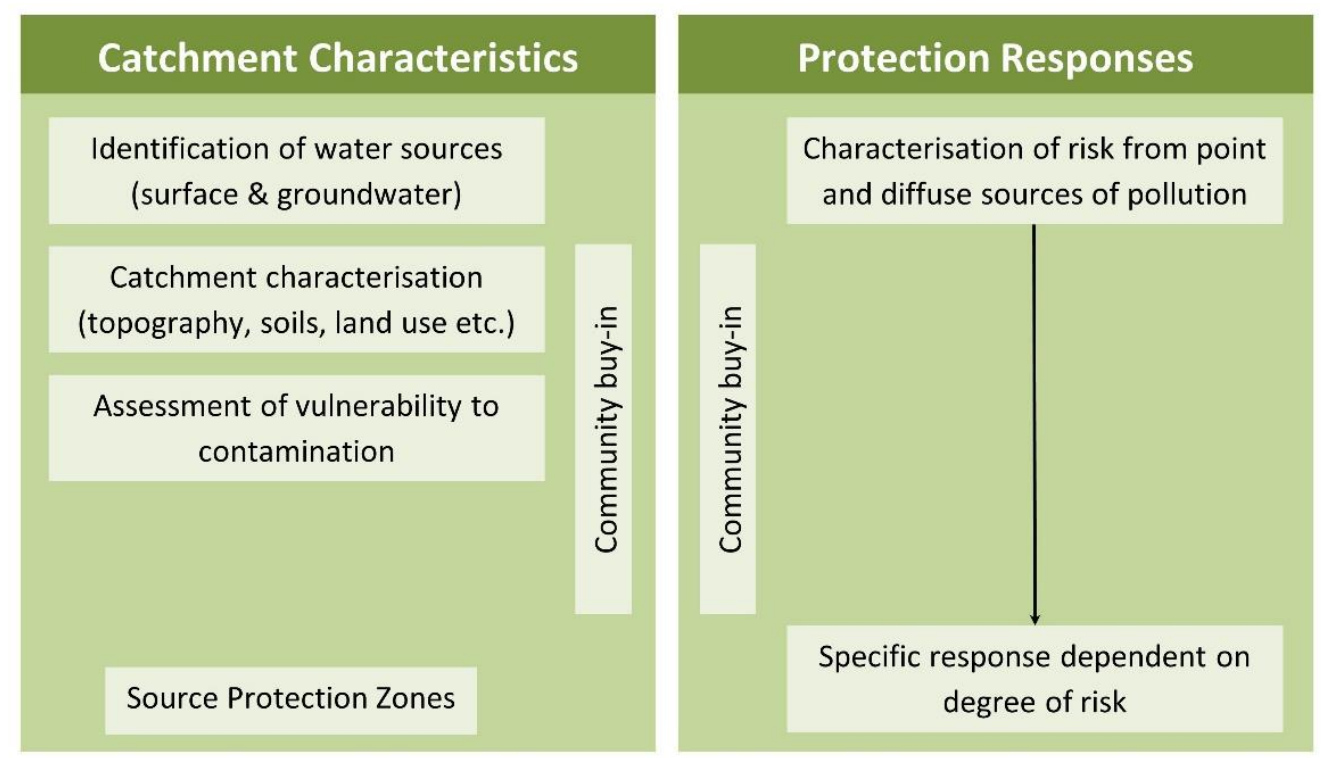

\section{Source Protection Strategy}

Figure 2. A framework for undertaking preliminary source protection assessments for Group Water Schemes in the Republic of Ireland abstracting from surface water sources (adapted from [1]).

Analysis of the physical catchment characteristics and of available water quality data resulted in the identification of priority source protection zones within a catchment. In combination with the identification of risk from sources of point and diffuse pollution, recommendations for the Group Water Scheme to implement were provided based on the priority source protection zones identified.

Drinking water quality data [29] for the years 2014-2018 inclusive were assessed for the number of exceedances per parameter across all privately sourced GWS abstracting from surface water sources.

\section{Results}

\subsection{Catchment and Group Water Scheme Characteristics and Exceedances of Water Quality Parameters}

The catchment area upstream of the Group Water Scheme abstraction points varied greatly across all surface water Group Water Schemes, but most are comparatively small (Figure 3). One-third (33.3\%) of surface water Group Water Scheme catchments are less than $2 \mathrm{~km}^{2}$; and $51.5 \%$ of catchments are less than $5 \mathrm{~km}^{2}$. Only $10.7 \%$ of catchments are larger than $100 \mathrm{~km}^{2}$; and $6.1 \%$ are larger than $1000 \mathrm{~km}^{2}$. Typically, the greater the population served by the Group Water Scheme, the greater the supply volume (Figure 4: $\left.\mathrm{R}^{2}=0.6659\right)$. The majority of Group Water Schemes abstracting from surface waters $(91 \%)$ serve a population of less than 3000 people, with $94 \%$ of Group Water Schemes supplying less than $1500 \mathrm{~m}^{3}$. Group Water Schemes supply both domestic and non-domestic (predominantly agricultural, but also some commercial) consumers, and consequently, it is not possible to estimate per capita consumption using the regression line presented in Figure 4. 


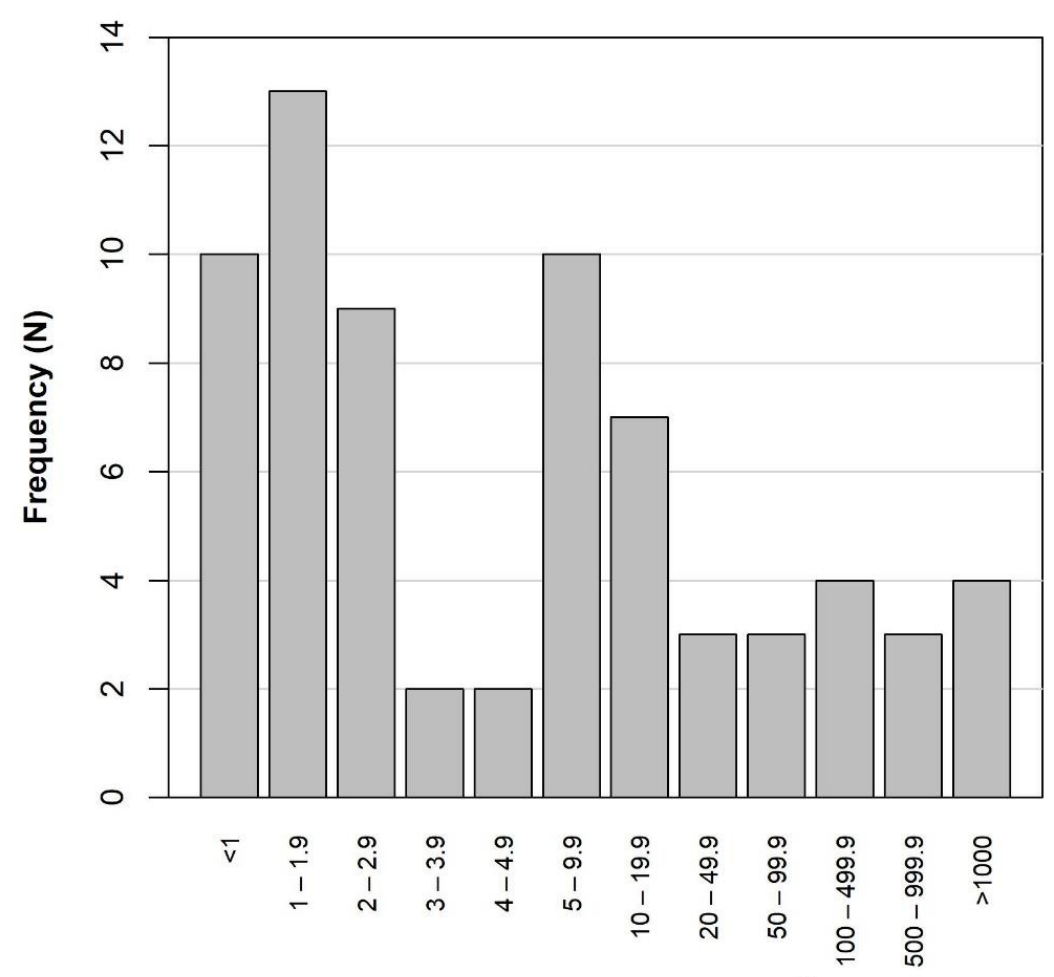

Catchment Size Range $\left(\mathrm{Km}^{2}\right)$

Figure 3. Frequency of surface water catchment sizes upstream from the point of Group Water Scheme abstraction.

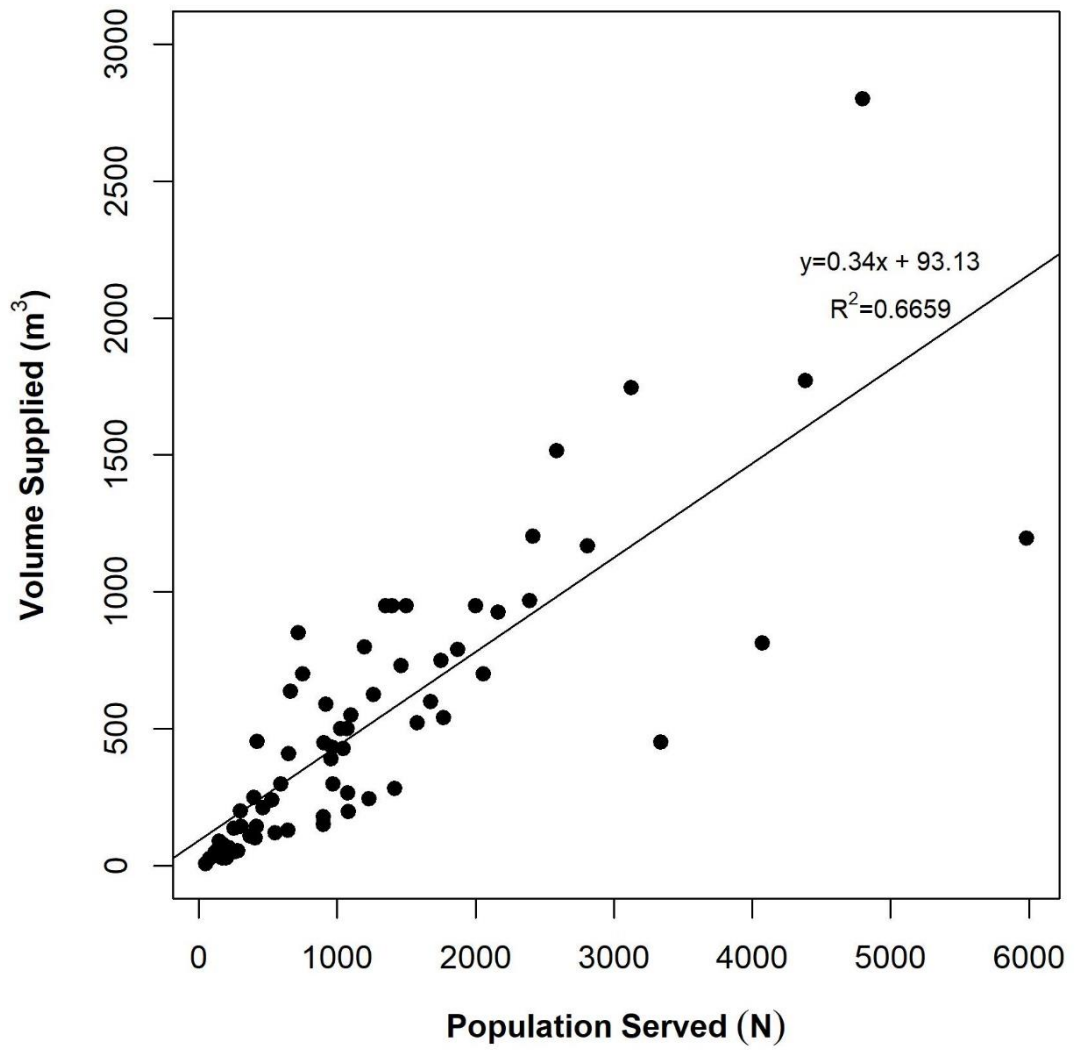

Figure 4. Supply volume (per day) and population served for Group Water Schemes abstracting from surface waters. 
Examining drinking water quality data for Group Water Schemes showed that exceedances of the Drinking Water Regulations (2014) were recorded across a total of 27 parameters (Figure 5). The greatest number of exceedances between 2014 and 2018 were due to total trihalomethanes, followed by coliform bacteria, colony count, colour, and aluminium.

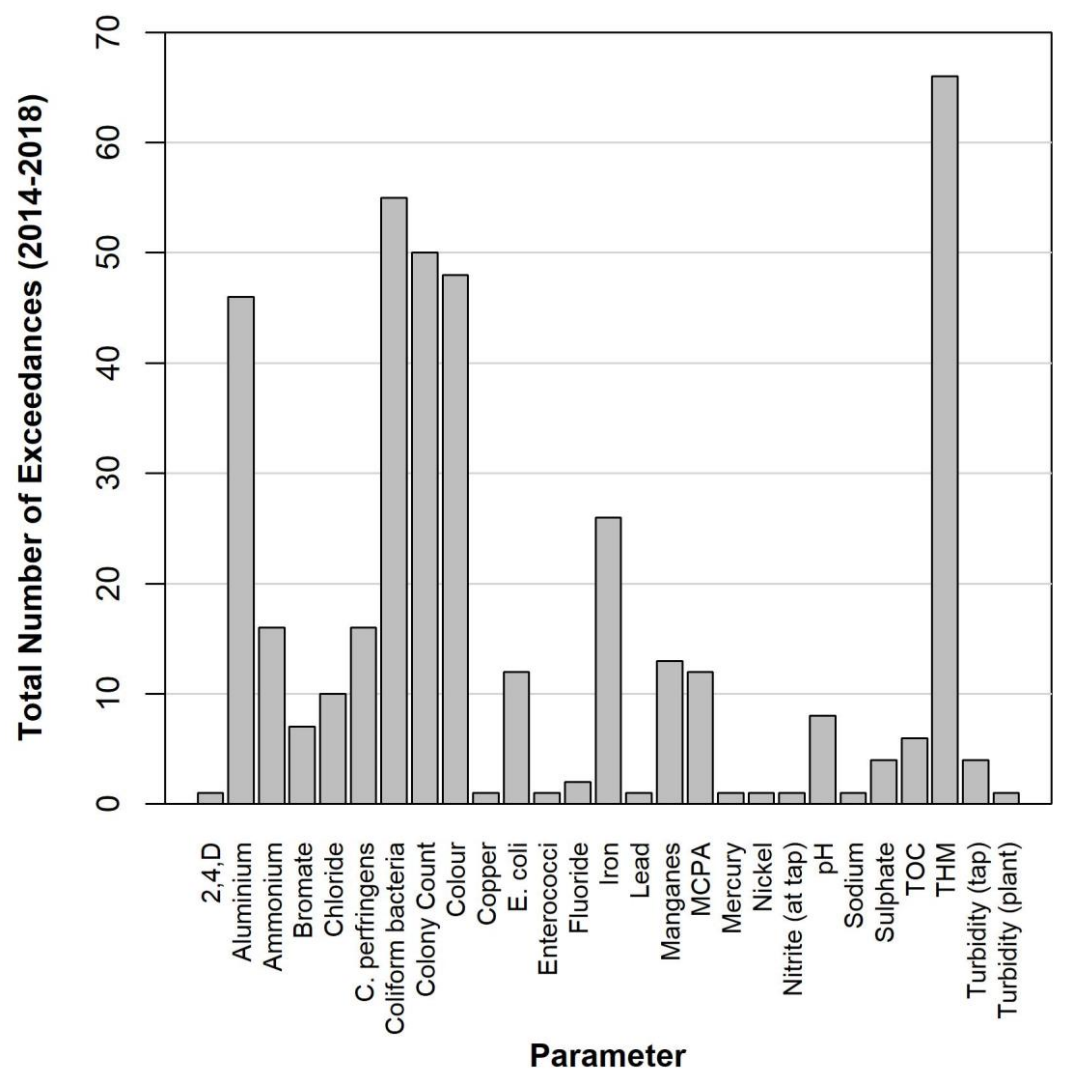

Figure 5. Total number of treated water exceedances of the Drinking Water Regulations (2014) per parameter from privately sourced Group Water Schemes (GWS) between 2014 and 2018.

\subsection{Preliminary Source Protection Recommendations}

Recommendations made through the 70 surface water preliminary source protection assessments undertaken between 2009 and 2019 were assigned to one of four groups (Figure 6): stakeholder engagement; water quality parameter monitoring; infrastructure/technical maintenance and management; and natural resource management actions.

The most frequent recommendation made was associated with the management of livestock access to local water bodies. Recommendations associated with such natural resource management (NRM) actions aimed at improving raw water quality represented $23.1 \%$ of all recommendations made. However, only two such NRM recommendations were made frequently: undertaking a survey of fencing or livestock access to waterbodies/fencing off water bodies, and undertaking an assessment of the groundwater zone of contribution to the abstraction point. This latter recommendation was typically made where there was a strong groundwater component to the surface water source such as localised groundwater spring locations, and where karstic limestone geology facilitates strong groundwater-surface water connectivity within the surface water catchment area. 


\begin{tabular}{lcc}
\hline \multicolumn{1}{c}{ Recommendation } & $\begin{array}{c}\text { Proportion of } \\
\text { Reports }\end{array}$ & Grouping \\
\hline Put Source Protection on the agenda of GWS committee meetings & 84.1 \\
Undertake a survey of fencing or livestock access to waterbodies/Fence off water bodies & 82.6 \\
Develop a protocol for dealing with pollution offenders & 73.9 \\
Establish a process for reporting of pollution incidences & 72.5 \\
Undertake further monitoring of raw water parameter(s) & 68.1 \\
Promote Good Agricultural Practice & 66.7 \\
Undertake engagement regarding domestic waste water treatment system management & 66.7 \\
Promote soil nutrient analysis within source water catchment & 66.7 \\
Revise treated water monitoring programme for total trihalomethanes & 59.4 \\
Undertake wider community engagement initiatives to increase local awareness of drinking water & 37.7 \\
issues & 34.8 \\
Review current, or commissionnew Cryptsporidium Risk Assessment & 34.8 \\
Engage Local Authority on specific issues & 33.3 \\
Undertake assessment of groundwater zone of contribution & 30.4 \\
Engage Design-Build-Operate (DBO) contractor regarding specific protocols or parameters & 26.1 \\
Engage local forestry owners/managers to adress current or potential future water quality & 15.9 \\
management & 10.1 \\
Maintain abstraction point or storage reservoir infrastructure & 10.1 \\
Revise current chlorination process & 4.3 \\
Investigate feasibility of relocation of abstraction point & 4.3 \\
Investigate treatment process options for specific raw water parameters & 2.9 \\
Address issues associated with flash flooding/flooding events & 2.9 \\
Undertake further monitoring of treated water parameter(s) & 2.9 \\
Undertake invasive species management & 2.9 \\
Restrict public access to abstraction point/infrastructure & 1.4 \\
Install sediment traps within inflow streams to reduce raw water turbidity and organic content & 1.4 \\
Address potential for over abstraction through improving distribution network leakage & \\
management & \\
Address localised turf cutting issues & \\
\hline
\end{tabular}

Recommendation Grouping

Stakeholder Engagement

Water Quality Parameter Monitoring

Infrastructure/Technical Management

Natural Resource Management Actions

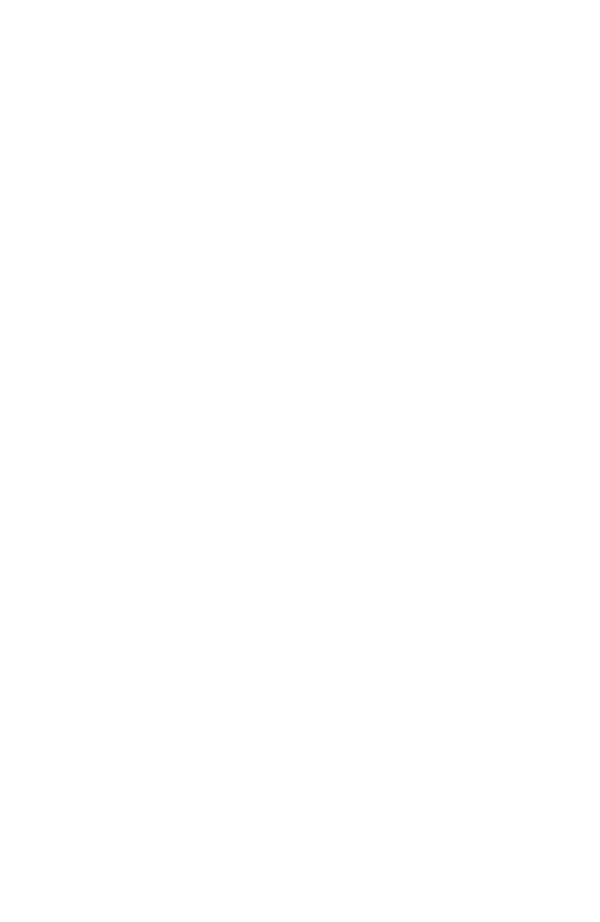

Figure 6. Summary of recommendations from 70 preliminary drinking water source protections reports for Group Water Schemes abstracting from surface water sources. 
Recommendations associated with stakeholder communication and awareness raising represented $38 \%$ of all recommendations made (Figure 6). The most frequent of these recommendations related to communications within individual Group Water Scheme committees to highlight the importance of drinking water source protection; and to develop internal protocols associated with managing pollution events and pollution offenders.

Inadequate raw water (untreated source water) quality monitoring was highlighted for $70.1 \%$ of the surface water Group Water Scheme, yet inadequate treated water monitoring was identified for only 3.0\% of Group Water Schemes. Water quality parameter monitoring represented $19.2 \%$ of all recommendations made.

Recommendations associated with infrastructure or technical maintenance and management represented $19.2 \%$ of all recommendations made yet were typically included for less than $14 \%$ of Group Water Schemes.

\section{Discussion}

Despite significant investment at a national scale to achieve the EU Water Framework Directive, the quality of the Republic of Ireland's water bodies continues to decline with nearly half of all surface water bodies ( $47.0 \%$ of rivers and $49.5 \%$ of lakes) currently in unsatisfactory condition-i.e., classified as being as less than 'good' status through WFD assessments [10]. Similar to many other parts of the EU, agricultural practices are often still regarded as a major factor in poor water quality [10,30-32], and as most Group Water Schemes are situated in rural areas, this adds to their challenges. As well as issues such as the nutrient pollution of waters, significant issues also include pesticides, pharmaceuticals, and microbial contamination-with recent increases in reported numbers of cases of Verocytotoxigenic E. coli (VTEC) resulting in the Republic of Ireland having the highest incidence of VTEC infection in Europe, with over $80 \%$ of primary cases related to contaminated water [32].

Action is required to improve the health of the Republic of Ireland's waters generally and to subsequently improve the services that these waters provide to the public, including high-quality drinking water. The parametric exceedances recorded across the GWS are a result of failures during the treatment process; issues within the source water; contamination of drinking water post-treatment; or a combination of all of these factors, highlighting the importance of drinking water source protection measures to improve drinking water quality.

Community-led actions have the potential to play a prominent role in improving water quality at the local scale, and subsequently at the national scale, not just in the Republic of Ireland but in other jurisdictions as well. For example, in the UK, River Basin Plans are actively engaging with people and organisations at a catchment level to improve the health of water [33]. The GWS sector is ideally placed to lead such community action in the Republic of Ireland through drinking water source protection measures in collaboration with relevant agencies and community groups. The fact that GWS have over many years built up a high level of trust within the sector should avoid top-down approaches and ensure that local expertise is engaged in the processes of creating and applying solutions [34].

While a large body of work remains to be undertaken, the progress made in drinking water source protection over the past 15 years in the Republic of Ireland provides a solid foundation for implementing a community-led catchment-based approach to improving drinking water quality at the national scale and addressing legacies of historical under-investment in drinking water infrastructure nationally [34].

Source protection has developed strongly as a model for improving drinking water quality in the Republic of Ireland and is included as a key measure for protected areas within the Republic of Ireland's second River Basin Management Plan 2018-2021 [9]. The State utility, Irish Water, is in the process of preparing and implementing Drinking Water Safety Plans for all public water supplies; subsequently, they are undertaking source risk assessments for each supply to identify sources that may require measures within the catchment to protect the drinking water source. Ireland's second RBMP 2018-2021 commits to a total of 353 source risk assessments being completed by Irish Water by 
the end of the 2nd RBMP cycle [9]. In addition, the second RBMP commits to a collaborative approach to drinking water source protection, particularly in relation to contamination from pesticides. For the Group Water Scheme sector, Phase II Drinking Water Source Protection Pilot Projects for two GWS were initiated in 2018 to follow on from the preliminary source protection assessments presented in this paper. The aim of these pilot projects are to develop fully integrated catchment management plans with each GWS to implement the recommendations made in the preliminary source protection assessments; and within which detailed assessments of, for example, nutrient critical source area and land use datasets are undertaken alongside the delivery of detailed catchment-scale water quality monitoring, community engagement, and educational programmes. The results of these pilot projects will inform the future roll-out of Phase II source protection projects across the GWS sector.

Drinking water source protection aims to improve the quality of drinking water to protect human health. Common factors that frequently contribute to public disease outbreaks due to the contamination of drinking water include inadequate knowledge of source water hazards, faecal contamination from livestock or wildlife, and extreme weather $[35,36]$. The former two factors are the two most frequent recommendations made within the preliminary source protection reports: 'Undertake a survey of fencing or livestock access to water bodies/fence off water bodies'; and 'Put source protection on the agenda for GWS committee meetings'. Cattle access to water courses can increase microbial contamination, nutrient contamination, and sedimentation [37,38]: all three can impact the quality of source water abstracted for drinking water. Fencing off all water bodies within large catchments is unrealistic; however, localised management actions either within smaller sub-catchments and/or close to drinking water abstraction points can be beneficial for improving source water quality [38]. The disparity in the adequate monitoring of raw water quality compared to treated water quality is likely a result of the differing legislative responsibilities placed on drinking water providers. The 1989 Surface Water Regulations [22] provide for the monitoring of surface water quality within three categories of standard methods for treating raw water. The frequency of monitoring of raw water quality parameters is dependent on the parameter and the population served, and the frequency is often left to be determined by the water supplier. For many GWS abstracting from surface waters, only a small number, if any, of the surface water quality parameters are frequently monitored, for example turbidity, $\mathrm{pH}$, and colour. In contrast for treated water, the 2014 Drinking Water Regulations [39] provide for more prescriptive monitoring of multiple drinking water parameters, the frequency of which is dependent on the volume of water produced or distributed each day within a supply zone.

Analysis of treated water exceedances of the 2014 Drinking Water Regulations identified total trihalomethanes (THMs) as the parameter for which such exceedances most frequently occurred. THMs are one of the principle disinfectant by-product (DBPs) formed following chlorination [40] and may potentially be carcinogenic to humans [41]. Chlorination is the most commonly used disinfection process in the Republic of Ireland. On 14 May 2020, the European Commission provided a reasoned opinion to the Republic of Ireland regarding its failure to fulfil its obligations under the Drinking Water Directive with regard to THM levels in drinking water supply zones and schemes [42]. This follows on from an infringement case brought against the Republic of Ireland by the EU in August 2018 for the persistent exceedance of THMs in drinking water. The escalation by the EC in May 2020 requires the Republic of Ireland to remedy the situation within four months of notice. The reasoned opinion covers all drinking water supply zones administered by Irish Water and the Group Water Scheme Sector as overseen by the National Federation of Group Water Schemes. Higher total THM concentrations in drinking water in the Republic of Ireland have been found to be associated with peat presence, shallow topographical slopes $(<5.25 \%)$, and higher than average rainfall [43]. Swift remedial action to reduce total THM concentrations is required to address the EC's reasoned opinion. Consequently, longer-term catchment-scale measures, for example to address peatland rehabilitation to reduce the dissolved organic carbon content of source waters which act as a precursor for THM formation, are unlikely to be progressed ahead of shorter-term engineering solutions within at-risk treatment plants. 
Following the completion of preliminary source protection assessments for all surface water-sourced Group Water Schemes, a key knowledge gap remains regarding how many recommendations have been implemented by schemes and the reasons for recommendations not being implemented. The potential for implementing recommendations and measures is likely higher in smaller catchments where actions may be less daunting for Group Water Schemes to implement as they can be delivered at the local level. As catchment size increases, the localised nature of measures reduces, creating greater difficulties for implementation and increasing the likely necessity of collaborative action within the catchment. Subsequently, for Group Water Schemes abstracting from large catchments, the delineation of more localised sub-catchments may be important for increasing the likelihood of implementation of recommendations.

\section{Conclusions}

Drinking water source protection actions for surface water sources have the potential to deliver multiple ecosystem services beyond solely improving drinking water quality. Such community-led catchment-scale actions have the potential to improve biodiversity, increase community awareness of and involvement in water-related initiatives, and increase resilience to future climate change. The challenges for improved water management associated with the projected increased likelihood of drier summers and wetter winters in the Republic of Ireland as a result of climate change must be addressed within the drinking water sector. These challenges have been highlighted by the occurrence of two droughts in 2018 and 2020 in the Republic of Ireland. The reduced availability of water resources led the Irish Government to implement, for the first time in 2018 and again in 2020, a Water Conservation Order (hosepipe ban) administered by the State utility, Irish Water, with the GWS sector also promoting water conservation measures and the wise use of water.

Of the 26 different recommendations made as part of preliminary source protection assessments, $10(38 \%)$ relate to stakeholder engagement. Consequently, drinking water source protection measures and catchment-scale actions have the potential to be an additional model to assist in the delivery of Integrated Catchment Management and River Basin Management Planning in the Republic of Ireland. As such, the drinking water source protection model can be used in synergy with other models, such as Rivers Trusts, which are garnering strong support at the national level for the community-led delivery of catchment management actions.

For the GWS sector, challenges for drinking water source protection lies in securing the resources required to improve both source water and drinking water quality monitoring in addition to delivering full integrated catchment management plans. Such resources include sustainable funding models and suitably qualified personnel. In addition, the current EU funding models around payments to farmers actually discourages land use for source protection, and the remodeling of the Common Agricultural Policy (CAP) may be an opportunity to address this.

Awareness raising and education initiatives are a critical component for encouraging collective action to improve source water and consequently drinking water quality. While the National Federation of Group Water Schemes have delivered frequent source protection-related education and awareness raising initiatives to Group Water Scheme Committees (e.g., training courses, annual conferences, newsletter articles), inherent difficulties occur where, as is often the case for Group Water Schemes, drinking water supply zones lie outside of the source water catchment areas. This means that local communities must be encouraged to undertake altruistic behavioural change to improve source water quality for another community's drinking water supply. To address this and other education and awareness raising challenges, two organisations were established through the $2^{\text {nd }}$ River Basin Management Plan: the Local Authority Waters Programme (LAWPRO) is charged with engaging communities to become more involved in local water management actions to improve water quality, including source protection actions; and An Fóram Uisce|The Water Forum, which is a statutory stakeholder body that provides guidance to the Irish Government on water-related matters and for 
which source protection is a core component of their strategy. An Fóram Uisce is also charged with increasing awareness of water-related issues through education initiatives.

However, the progress made in drinking water source protection over the past 15 years in the Republic of Ireland provides a solid foundation for implementing a community-led catchment-based approach to improving drinking water quality at the national scale and further afield.

Author Contributions: Conceptualisation, A.R.; Formal analysis, A.R. and S.L.; Funding acquisition, A.R.; Investigation, A.R. and S.L.; Methodology, A.R. and S.L.; Project administration, A.R.; Resources, A.R. and S.L.; Visualisation, A.R.; Writing-original draft, A.R. and S.L.; Writing-review and editing, A.R. and S.L. All authors have read and agreed to the published version of the manuscript.

Funding: Initial funding to undertake preliminary source protection assessments were provided by individual Group Water Schemes through the Irish Government's Rural Water Programme.

Acknowledgments: The authors would like to acknowledge the support of the National Federation of Group Water Schemes in undertaking this body of work, as well as the contributions and assistance provided by all individual Group Water Schemes for which preliminary source protection assessments were undertaken.

Conflicts of Interest: The authors declare no conflict of interest.

\section{References}

1. Linnane, S.; Jordan, S.; McCarthy, V.; Jennings, E.; Carson, A.; Sweeney, N.; Wynne, C.; McDonald, B. National Source Protection Pilot Project Final Report 2005-2010; National Rural Water Services Committee: Dublin, Ireland, 2011; Available online: https://www.dkit.ie/system/files/nsppp_final_report_2005-2010.pdf (accessed on 29 July 2020).

2. Sayato, Y. WHO guidelines for drinking-water quality. Eisei kagaku 1989, 35, 307-312. [CrossRef]

3. Retallack, M. Paradigmatic policy change or unintended subordination of rural autonomy: The case of source water protection in Ontario, Canada. Policy Sci. 2020, 53, 85-100. [CrossRef]

4. Sweeney, J.; Albanito, F.; Brereton, A.; Caffarra, A.; Charlton, R.; Donnelly, A.; Fealy, R.; Fitzgerald, J.; Holden, N.; Jones, M.; et al. Climate Change—Refining the Impacts for Ireland; Environmental Protection Agency of Ireland: Wexford, Ireland, 2008. Available online: https://www.epa.ie/pubs/reports/research/climate/ sweeney-report-strive-12-for-web-low-res.pdf (accessed on 29 July 2020).

5. Coll, J.; Sweeney, J. Current and Future Vulnerabilities to Climate Change in Ireland; Environmental Protection Agency of Ireland: Wexford, Ireland, 2013. Available online: https://www.epa.ie/pubs/reports/research/ climate/CCRP_29.pdf (accessed on 29 July 2020).

6. Roudier, P.; Andersson, J.C.M.; Donnelly, C.; Feyen, L.; Greuell, W.; Ludwig, F. Projections of Future Floods and Hydrological Droughts in Europe under a $+2{ }^{\circ} \mathrm{C}$ Global Warming. Clim. Chang. 2015, 135, 341-355. [CrossRef]

7. Mehan, S.; Kannan, N.; Neupane, R.P.; McDaniel, R.; Kumar, S. Climate Change Impacts on the Hydrological Processes of a Small Agricultural Watershed. Climate 2016, 4, 56. [CrossRef]

8. Rolston, A. Water management: Social changes affect water quality too. Nature 2016, 536, 396. [CrossRef] [PubMed]

9. DHPLG. River Basin Management Plant for Ireland 2018-2021; Department of Housing, Planning and Local Government: Dublin, Ireland, 2018. Available online: https:/www.housing.gov.ie/sites/default/files/ publications/files/rbmp_full_reportweb.pdf. (accessed on 29 July 2020).

10. EPA. Water Quality in Ireland 2013-2018; Environmental Protection Agency: Wexford, Ireland, 2019. Available online: https://www.epa.ie/pubs/reports/water/waterqua/waterqualityinireland2013-2018.html (accessed on 29 July 2020).

11. Mooney, K.M.; Hamilton, J.T.G.; Floyd, S.D.; Foy, R.H.; Elliott, C.T. Initial studies on the occurrence of cyanobacteria and microcystins in Irish lakes. Environ. Toxicol. 2010, 26, 566-570. [CrossRef] [PubMed]

12. Touzet, N.; McCarthy, D.; Gill, A.; Fleming, G. Comparative summer dynamics of surface cyanobacterial communities in two connected lakes from the west of Ireland. Sci. Total Environ. 2016, 553, 416-428. [CrossRef] [PubMed]

13. EPA Catchments. Significant Pressures: Agriculture; Environmental Protection Agency of Ireland: Wexford, Ireland, 2019. Available online: https://www.catchments.ie/significant-pressures-agriculture/ (accessed on 29 July 2020). 
14. EPA. Protecting Drinking Water Supplies: Drinking Water Safety Plans; Environmental Protection Agency of Ireland: Wexford, Ireland, 2019. Available online: https://epa.ie/water/dw/protectingdrinkingwatersupplies/ (accessed on 29 July 2020).

15. NFGWS. A Framework for Drinking Water Source Protection; National Federation of Group Water Schemes: Monaghan, Ireland, 2019; Available online: https://nfgws.ie/a-framework-for-drinking-water-sourceprotection-2/ (accessed on 29 July 2020).

16. EPA. Drinking Water Report for Public Supplies 2017; Environmental Protection Agency: Wexford, Ireland, 2018. Available online: http://www.epa.ie/pubs/reports/water/drinking/2017\%20DW\%20Report_web_Final.pdf (accessed on 29 July 2020).

17. EPA. Drinking Water Monitoring Results and Water Supply Details for Ireland-Year 2017; Environmental Protection Agency of Ireland: Wexford, Ireland, 2018. Available online: http://erc.epa.ie/safer/resource?id= a0889eb7-6e74-11e8-b825-005056ae0019 (accessed on 29 July 2020).

18. Brady, J.; Gray, N.F. Group Water Schemes in Ireland-Their Role within the Irish Water Sector. Eur. Water 2010, 29, 39-58. Available online: https://www.ewra.net/ew/pdf/EW_2010_29_05.pdf (accessed on 29 August 2020).

19. Eurostat. Eurostat Regional Yearbook 2019. Available online: https://ec.europa.eu/eurostat/statisticsexplained/index.php?title=Eurostat_regional_yearbook (accessed on 29 July 2020).

20. NFGWS. Ireland's Community-Owned Rural Water Sector: Background E Early Development; National Federation of Group Water Schemes: Monaghan, Ireland, 2019; Available online: https://nfgws.ie/background-to-thegws-sector/ (accessed on 29 July 2020).

21. NFGWS. A Strategy for Source Protection on Group Water Schemes; National Federation of Group Water Schemes: Monaghan, Ireland, 2012; Available online: https://nfgws.ie/wp-content/uploads/2019/06/Group-WaterScheme-Source-Protection-Strategy-20-November-2012.pdf (accessed on 29 July 2020).

22. Surface Water Regulations. S.I No. 294/1989-European Communities (Quality of Surface Water Intended for the Abstraction of Drinking Water) Regulations. 1989. Available online: http://www.irishstatutebook.ie/ eli/1989/si/294/made/en/print\# (accessed on 21 August 2020).

23. River Basin Management Plans 2009-2015. Available online: http://www.wfdireland.ie/docs/1_River\% 20Basin\%20Management\%20Plans\%202009\%20-\%202015/ (accessed on 25 August 2020).

24. Environmental protection Agency of Ireland. Protecting Drinking Water Supplies. Available online: https://www.epa.ie/water/dw/protectingdrinkingwatersupplies/ (accessed on 25 August 2020).

25. Rolston, A.; Jennings, E.; Linnane, S. Water matters: An assessment of opinion on water management and community engagement in the Republic of Ireland and the United Kingdom. PLoS ONE 2017, 12, e0174957. [CrossRef]

26. Environmental Protection Agency of Ireland Geoportal Site. Available online: http://gis.epa.ie/ (accessed on 29 July 2020).

27. Geological Survey of Ireland Data and Maps. Available online: https://www.gsi.ie/en-ie/data-and-maps/ Pages/default.aspx (accessed on 29 July 2020).

28. Catchments.ie. Available online: https://www.catchments.ie/ (accessed on 29 July 2020).

29. EPA. Secure Archive for Environmental Research Data; Environmental Protection Agency of Ireland: Wexford, Ireland, 2012. Available online: http://erc.epa.ie/safer/ (accessed on 29 July 2020).

30. EPA. Drinking Water Report for Public Water Supplies 2018; Environmental Protection Agency: Wexford, Ireland, 2019. Available online: https://www.epa.ie/water/dw/quality/ (accessed on 29 July 2020).

31. Harrison, S.S.C.; McAree, C.; Mulville, W.; Sullivan, T. The problem of agricultural 'diffuse' pollution: Getting to the point. Sci. Total Environ. 2019, 677, 700-717. [CrossRef]

32. DHPLG. Significant Water Management Issues in Ireland Public Consultation Document; Department of Housing, Planning and Local Government: Dublin, Ireland, 2019. Available online: https://www.housing.gov.ie/water/ water-quality/water-framework-directive/public-consultation-significant-water-management (accessed on 29 July 2020).

33. Whitman, G.P.; Pain, R.; Milledge, D. Going with the flow? Using participatory action research in physical geography. Prog. Phys. Geogr. Earth Environ. 2015, 39, 622-639. [CrossRef]

34. Bresnihan, P.; Hesse, A. Political ecologies of infrastructural and intestinal decay. Environ. Plan. E Nat. Space 2020. [CrossRef]

35. Hrudey, S.E.; Hrudey, E.J.; Pollard, S.J. Risk management for assuring safe drinking water. Environ. Int. 2006, 32, 948-957. [CrossRef] 
36. Merrett, H.C.; Chen, W.T.; Horng, J.-J. A Systems Analysis Approach to Identifying Critical Success Factors in Drinking Water Source Protection Programs. Sustainability 2019, 11, 2606. [CrossRef]

37. O'Callaghan, P.; Kelly-Quinn, M.; Jennings, E.; Antunes, P.; O’Sullivan, M.; Fenton, O.; O’hUallacháin, D. Impact of Cattle Access to Watercourses: Literature Review on Behalf of the COSAINT Project; Environmental Protection Agency of Ireland: Wexford, Ireland, 2018. Available online: http://www.epa.ie/ researchandeducation/research/researchpublications/researchreports/Research_Report_260.pdf (accessed on 29 July 2020).

38. O'Sullivan, M.; Huallacháin, D.Ó.; Antunes, P.O.; Jennings, E.; Kelly-Quinn, M. The impacts of cattle access points on deposited sediment levels in headwater streams in Ireland. River Res. Appl. 2019, 35, 146-158. [CrossRef]

39. Drinking Water Regulations. S.I. No. 122/2014-European Union (Drinking Water) Regulations 2014. Available online: http://www.irishstatutebook.ie/eli/2014/si/122/made/en/print (accessed on 21 August 2020).

40. United States Environmental Protection Agency. Six-Year Review 3 Technical Support Document for Disinfectants/Disinfection Byproducts Rules. 2016. Available online: https://www.epa.gov/sites/production/ files/2016-12/documents/810r16012.pdf. (accessed on 29 August 2020).

41. Villanueva, C.; Cordier, S.; Font-Ribera, L.; Salas, L.A.; Levallois, P. Overview of Disinfection By-products and Associated Health Effects. Curr. Environ. Health Rep. 2015, 2, 107-115. [CrossRef] [PubMed]

42. European Commission. May 2020 Infringements Package: Key Decisions. Available online: https: //ec.europa.eu/commission/presscorner/detail/en/inf_20_859 (accessed on 23 August 2020).

43. O'Driscoll, C.; Sheahan, J.; Renou-Wilson, F.; Croot, P.; Pilla, F.; Misstear, B.; Xiao, L. National scale assessment of total trihalomethanes in Irish drinking water. J. Environ. Manag. 2018, 212, 131-141. [CrossRef] [PubMed]

(C) 2020 by the authors. Licensee MDPI, Basel, Switzerland. This article is an open access article distributed under the terms and conditions of the Creative Commons Attribution (CC BY) license (http://creativecommons.org/licenses/by/4.0/). 